\title{
What did they learn in school today? A method for exploring aspects of learning in physical education
}

European Physical Education Review 2014, Vol. 20(2) 282-302

(C) The Author(s) 2014

Reprints and permission: sagepub.co.uk/journalsPermissions.nav DOI: 10.1 I $77 / 1356336 \times 14524864$ epe.sagepub.com

@SAGE

\section{Mikael Quennerstedt}

Örebro University, Sweden

\section{Claes Annerstedt}

University of Gothenburg, Sweden

\section{Dean Barker}

University of Gothenburg, Sweden

\section{Inger Karlefors}

Umeå University, Sweden; Luleå University of Technology, Sweden

\section{Håkan Larsson}

The Swedish School of Sport and Health Sciences, Sweden

\section{Karin Redelius}

The Swedish School of Sport and Health Sciences, Sweden

\section{Marie Öhman}

Örebro University, Sweden

\begin{abstract}
This paper outlines a method for exploring learning in educational practice. The suggested method combines an explicit learning theory with robust methodological steps in order to explore aspects of learning in school physical education. The design of the study is based on sociocultural learning theory, and the approach adds to previous research within the field, both in terms of the combination of methods used and the claims made in our studies. The paper describes a way of collecting and analysing the retrieved data and discusses and illustrates the results of a study using this combination of explicit learning theory and robust methodological steps.
\end{abstract}

\section{Corresponding author:}

Mikael Quennerstedt, School of Health and Medical Sciences, Örebro University, Örebro 70I 82, Sweden.

Email: mikael.quennerstedt@oru.se 


\section{Keywords}

Learning, sociocultural, video, didactic moments, research method

\section{Introduction}

What do students learn in the school subject of physical education (PE), and how can learning in this subject be investigated? In this paper we propose a method for exploring different aspects of learning in PE practice. The proposed methodological strategy involves sociocultural learning theory, the use of different data and rigorous methodological steps. We suggest that it is the combination of an explicit learning theory and robust methods used to explore ongoing PE practices that makes our claims about exploring learning in PE possible.

Recent literature pertaining to the field of PE has demonstrated different ways of using learning theories in PE practice. These approaches are based on behaviourist, constructivist, ecological, situated, or didactic perspectives (see Amade-Escot, 2006; Barker et al., 2013; Chen and Ennis, 2004; Deglau and O'Sullivan, 2006; Dyson et al., 2010; Kirk and Macdonald, 1998; Light, 2011; Rovegno, 2006; Rovegno and Dolly, 2006; Rovegno et al., 2001; Wallian and Chang, 2006; Ward and Lee, 2005). This research reveals that learning in PE can be understood in different ways. Several of these scholars also conclude that exploring learning empirically is a complex issue and that the diversity of perspectives probably contributes to this complexity.

From this scenario it seems to follow that relatively few empirical studies grounded in theories of learning have covered what students learn in PE practice and how they do this, i.e. studies that focus on the individual learner without losing track of the social, cultural and institutional aspects of learning and, in particular, those that include embodied aspects of movement (see, for example, Rovegno, 2006; Rovegno and Dolly, 2006). By 'relatively few', we mean relative to the number of studies of learning in other school subjects, such as science education or mathematics. In PE research, the focus has often been on the content (curriculum) and the teaching of the subject (Kirk et al., 2006), where learning theories sometimes have the tentative function of providing guidance for curriculum development, curriculum models or teaching strategies (see, for example, Jess et al., 2011; Kirk and Macdonald, 1998; Light, 2008; Macdonald, 2004; Rovegno and Dolly, 2006).

There is however a strong and important tradition in PE research using critical sociocultural theories of, for example, Foucault and Bourdieu, or more gendered, racial, class or sexuality oriented approaches (for recent examples see: Brown and Penney, 2013; Cliff, 2012; Gillespie, 2013; Hay and Penney, 2012; O'Sullivan, 2013; Wright et al., 2012). Many of these scholars also explore and discuss empirical findings in relation to learning, as we do here, but without necessarily employing an explicit learning theory to explore learning in educational practice. A notable exception is research conducted with the use of Basil Bernstein, where several scholars in the field of PE have proposed concepts like corporeal device to understand embodied learning (e.g. Evans et al., 2009, 2011; Ivinson, 2012) and explored PE practice in terms of teaching and educational values (e.g. Evans et al., 1996). Another interesting exception is Barker and colleagues (2013), who use a social constructionist perspective in order to explore ethics in PE with the use of interactive episodes. However, relatively few attempts have been made from these important strands of research to thoroughly develop and 
describe methodological designs and steps in order to investigate what students learn when participating in PE practice together with how the ongoing learning processes can be analysed and described.

One attempt to explore learning in PE practice using learning theory and a rigorously described methodological design has been made within the French didactique tradition. In several publications, Chantal Amade-Escot and colleagues have shown how three aspects of teaching and learning can be understood and investigated as 'the functioning of the 'didactic system' which links teacher, content knowledge and students in classroom and gymnasium' (Amade-Escot, 2006: 347; see also Amade-Escot and O’Sullivan, 2007; Verscheure and Amade-Escot, 2007). In her keynote lecture at the AIESEP World Congress in 2008, Amade-Escot explained how situated explorations of the ecological context of classrooms or gyms can help us to acquire a deeper understanding of how content is brought into play in educational practice, and how the teaching and learning processes fit into this framework. A research method used in this strand of research was presented in an inspirational yet surprisingly under-used paper in the Journal of Teaching in Physical Education (Amade-Escot, 2005). In this paper, Amade-Escot describes how didactic observation in combination with pre- and post-lesson interviews can be used to explore aspects of teaching and learning in PE practice.

Another important effort involves the use of situated learning theory. In this context, MacPhail and colleagues (2008) and Kirk and colleagues (2000) argue that learning can be understood and explored as how students actively engage with institutionalised subject matter in terms of three dimensions of situativity: perceptual/physical, social/interactive and institutional/cultural. The perceptual/physical dimension refers to the physical environment and students' engagement with this environment, the social/interactive dimension refers to the relations between people in the situation, and institutional/cultural dimension refers to the cultural resources that students bring to the situation, as well as the values of the school and popular movement culture (Kirk et al., 2000). This research examines the relation between the three dimensions and mainly focuses on pedagogical models like TGfU or sport education using video-recorded lessons, diaries and interviews with teachers and students (see e.g. Kirk and MacPhail, 2002; MacPhail et al., 2008; Rovegno et al., 2001).

Against this background, the purpose of this article is to build on the research within didactique and situated learning in PE and to suggest an additional way of exploring issues of learning in educational practice. The methodological approach that we are proposing involves a combination of an explicit learning theory, the use of different data and clearly described methodological steps. This approach adds to previous research both in the methods used and the claims made in our studies. Accordingly, we will describe a way of collecting and analysing data and will also discuss and illustrate the results of a study using this particular approach.

The design of the study is based on what sometimes is labelled a sociocultural learning theory often with a base in the work of Vygotsky or Dewey ${ }^{1}$ (see Lave and Wenger, 1991; Rogoff, 1995; Säljö, 1998, 2009; Sfard, 1998; Wertsch, 1998). Hence, in this article, learning is advanced as an ongoing relation between teachers, students and the cultural/institutional prerequisites of the learning situation (Amade-Escot, 2006; Quennerstedt et al., 2011; Rovegno et al., 2001; Verscheure and Amade-Escot, 2007). A central element in our methodological strategy is the decisive aspect of the content of the teaching that is important for the students' understanding and learning in ongoing PE practice. In view of this, an approach has been developed that utilises pre- and post-lesson interviews with the concerned teachers, video-recorded lessons and interviews with teachers and students with a point of departure in identified 'didactic moments' 
from the recorded lessons, i.e. events in the lessons that appear to play an important part in the on-going learning processes.

We argue that this combination of using learning theory and different data makes it possible to explore learning in PE practice, adding to the didactique and situated perspectives by attending to issues concerning embodied learning, individual experiences and wider institutional and cultural influences on the learning situation (see Quennerstedt et al., 2011). It is consequently the amalgamation of an explicit learning theory with robust methods that makes our claims about learning possible.

\section{Background - the thinking behind the method}

The methods that are presented in this article have been developed within a larger research project entitled 'Physical education - a subject for learning?' Swedish Research Council (ref no 721-20105182). The overall purpose of this project is to investigate knowledge formation, teaching and learning in the school subject of PE in Sweden by answering the following questions: what kind of learning and knowledge appear to be relevant in PE?; how is this knowledge visible in PE practice?; what kind of learning is promoted in PE with regard to different kinds of teaching and assessing?

The approach is underpinned by sociocultural learning theory (see Cobb and Bowers, 1999; Hodkinson et al., 2007, 2008; Rogoff, 1995; Säljö, 1998; 2009; Sfard, 1998; Wertsch, 1998; Wickman and Östman 2002). This theoretical strand directs the focus towards students' participation in activities that constitute the content of the teaching and the conceptions, values, norms and views that dominate the subject (Almqvist et al., 2008; Rogoff, 1995; Wertsch, 1998). Sociocultural learning theory is based on the idea that knowledge is constituted in a social context and, consequently, that interaction and communication between people are crucial for learning (Säljö, 1998; 2009; Wertsch, 1998).

The task of a sociocultural approach is to explicate the relationship between human action, on the one hand, and the cultural, institutional and historical contexts in which action occurs on the other (Wertsch, 1998: 24).

Learning is seen as a social production of meaning in the relation between the individual's situated experiences and the institutional context. Also, according to sociocultural theories of learning, knowing is very close to communities of practice and the individual's ability to participate in these practices (Lave and Wenger, 1991; Sfard, 1998). Accordingly, knowledge formation and learning never exist in a vacuum, but are always 'situated', i.e. woven into a historical and cultural context. The ability to take part in social practices is therefore essential (Lave and Wenger, 1991).

Sociocultural learning theory is also based on the premise that learning - and the will to learn is dependent on the meaning the individual ascribes to the activity, that is, how the individual makes 'the world' understandable in a certain situation (Almqvist et al., 2008; Rogoff, 1995; Säljö, 2009; Wertsch, 1998). In a sports context, this implies that people invest in the effort that is required to participate and be physically active in a particular context and acquire the required bodily competences for participation, especially if the groups to which they feel they belong consider this investment important. Particular emphasis is placed on how people develop and use physical- and verbal tools or artefacts (Säljö, 1998; Wertsch 1998). Hence, communicative processes are of central importance (Säljö, 2009). Likewise, being able to do something (read, do 
arithmetic, write, practise sports, etc.) usually implies that the individual masters a certain communicative practice. Language thus assumes a central role in studies using sociocultural learning theory. This idea can be traced back to Vygotsky (1986), together with the notion that action is mediated through the linguistic tools that people develop and use. However, in our study, language does not merely refer to speech or text, but has a wider significance, namely that which has meaning and has been made into language (Almqvist et al., 2008; Quennerstedt et al., 2011). In this way, verbal and bodily actions can be taken into consideration and bridge the dualism between cognitive and embodied learning. Hence, Hodkinson et al. (2008) argue that we must go beyond this dualism in socioculturally inspired studies of the content and process of learning (see also Light, 2011). Although PE practice includes verbal communication, most of the communication takes place via movement (that always has a communicative content), and also artefacts such as balls, gymnastic apparatuses, fixtures in the gymnasium and so on are also of great importance for students' learning in PE practice (Quennerstedt et al., 2011).

In line with Kirk and colleagues (2000), we would argue that aspects of learning in PE can be socioculturally attended to as a process in which the individual aspect (students' previous experiences re-actualised in the situation), the social aspect (relations with other people) and the cultural/ institutional aspect (knowledge and curriculum content shaped through the cultural, institutional and 'physical' context on offer in the situation) can be explored as participants in the learning process. In our studies, this allows us to explore different aspects of the learning processes that take place in the gym or outdoors (see MacPhail et al., 2008; Quennerstedt et al., 2011; Rogoff, 1995). We also concur with MacPhail et al. (2008) that these aspects of 'situativity may be constructs that are robust enough to warrant further testing and refinement in physical education and youth sport' (113).

We have also tried to take heed of Hodkinson et al. (2007), in their warnings to scholars using existing cognitive and situated theories of learning, who maintain that there is:

- A tendency for individual differences and individual learning to disappear, with the focus on social interactions, activities and participation $[\ldots]$.

- A tendency to focus on the particular site where learning takes place (such as a specific workplace), thus bracketing off and largely ignoring wider social, cultural and structural influences.

- A tendency to downplay issues of inequality and power relations within and beyond the site $[\ldots]$.

- A tendency to separate out the agency of individual learners from the social structures that they are seen to inhabit, focussing on one or the other, not both.

- A tendency for the majority of post-Vygotskian research and theorizing on learning to retain a concentration on cognition, rather than seeing learning as practical and embodied [...]. (Hodkinson et al., 2007: 417)

Like the previously mentioned didactique and situated approaches in PE research on learning, we take points four and five into account. However, we would argue that our perspective adds to these approaches by also attending to Hodkinson and colleagues' (2007) first three points.

In this paper, we suggest that investigating the practice of PE and exploring what appears in specific situations or events in terms of what can be observed in them can be a way of getting empirically closer to issues of learning in PE. This involves exploring and describing the individual, social and cultural/institutional aspects of the learning situation by means of the functions they constitute in the explored ongoing practice (see Light, 2011; Quennerstedt et al., 2011). In 
the following section we are describing an example of the methodological strategy that was used to study PE practice in eight schools in terms of learning. We will recount practical steps and methodological choices used, and supplement this discussion with empirical examples that enhance this discussion.

\section{The steps used - describing the data collection}

In the larger research project, a project conducted by seven senior researchers from four different universities, data was collected at eight schools in four different cities in Sweden. In order to maintain a methodological rigour, a clear and easy guide to the step-by-step data collection was created, starting with the purposes and research questions of the study.

In line with Alvesson and Sköldberg's (2000) call to approach data reflexively, we attempted to use the emerging empirical material to inform the data production in subsequent steps. The prelesson teacher interviews and video observations were used to develop questions for the postlesson teacher interviews. Similarly, the didactic moment interviews (developed later in the paper) could not have been completed without first working with the observational material. This approach meant that an analysis took place throughout the various steps, even though we refer to these activities here as data collection.

\section{Potential research questions addressed through this approach}

With the earlier stated research questions of the project in mind, the individual, social and cultural/institutional aspects of learning were explored and described in terms of the functions they constitute in the investigated practice. However, in a specific study, one of the aspects can be put in the foreground without taking the other aspects out of the equation. By asking certain questions, one aspect can be emphasised in the study, but without leaving the other aspects out all together, since they all constitute a whole in the theoretical perspective used. The following are examples of questions that can be used to pinpoint the different aspects.

\section{The cultural/institutional aspect}

What cultural norms do the different activities in the PE curriculum convey? How do students learn to deal with these norms constructively in order to participate? Which norms are expressed and what appears to be the subject's objects of knowledge? What kind of attitudes to sport, body and health are made possible and promoted in the studied situations? How are different kinds of knowledge valued and judged in practice? How do societal

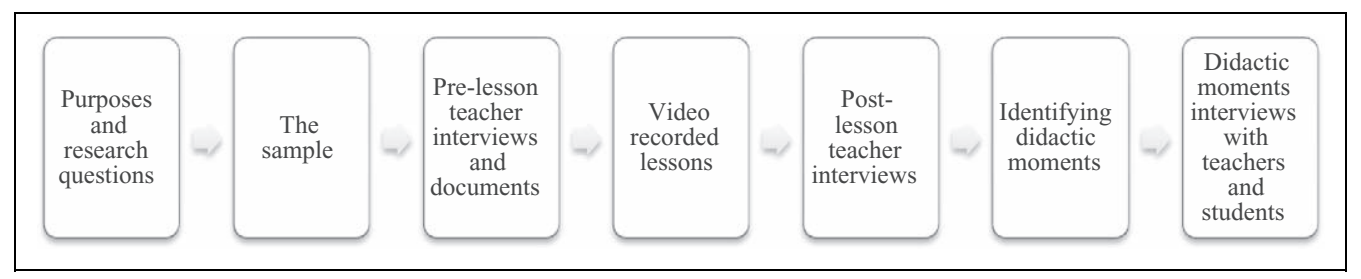

Figure I. Chronology of data collection. 
discourses about matters like fitness and health come into play in the practice of PE, and how do they affect students' learning?

The social aspect

How do students negotiate the cultural norms that are brought into play in the PE practice? What and how do students learn in the subject? How and in which direction is the learning promoted by the learning content and by the teachers through pedagogical transaction? Which attitudes toward sport, body and health are made possible and promoted in the studied situations and teaching practices? What and how do students help each other to learn? How do teachers communicate the aims and purposes of a particular lesson to students? How are students able to express what they are supposed to learn?

The individual aspect

Which experiences do the students re-actualise in the studied situation? Which institutional preconditions for teaching in terms of subject traditions, aims and expectations are manifested in the students' actions? How do the students relate to institutionalised discourses in the subject?

All the above questions can potentially be addressed by using the proposed method of approach.

\section{The sample}

As in all studies, the sample used when studying learning is of great importance. It is also dependent on which research question is being explored. The sample in our study was based on an idea to both try to capture variation in the explored teaching practices and to make use of the researchers' geographical distribution across the country.

The empirical studies were conducted in two classes in each of the four cities in which the researchers carried out their project work, i.e. a total of eight classes in eight different schools. This ensured a geographical distribution across the country as a whole and the inclusion of different types of communities - large city, middle-sized town and densely populated area. The selection of classes and schools was strategically made with regard to level: lower secondary (years 7-9) or upper secondary (years 10-12), profile (academic and vocational profile and general profile, sports profile or health profile) and classes that in other ways signalled different PE practices. The data collection was conducted in a similar way in all the classes (see Figure 1).

\section{Pre-lesson teacher interviews and curriculum documents}

An interview guide was created for the pre-lesson teacher interviews in order to capture the context and purpose of the forthcoming PE lesson (see Appendix 1). The interviews were conducted in direct connection to the video-recorded lessons, and the questions that were asked were related to issues of knowledge, teaching and processes of learning in the upcoming lesson.

In addition, lesson plans, schedules, theme plans, term plans, local policy documents, grading criteria and the like were collected in order to acquire more information about the institutional prerequisites of $\mathrm{PE}$ at each school. 


\section{The video recordings}

Two cameras were used for the video-recordings. One camera was placed on a tripod in a corner of the gym in order to capture the collective actions of the students, the environment and the artefacts used. The other camera was held by one of the researchers who moved around in order to capture important instructions, relations, communications and close-up movements (see MacPhail et al., 2008; Öhman and Quennerstedt, 2012; Rønholt, 2002). With this camera it was also easier to record the students' voices and discussions in the noisy environment of the gym. Between three and five lessons at each school were video-recorded in the project.

\section{Post-lesson teacher interviews}

An interview guide was created for the post-lesson teacher interviews in order to connect to the pre-interviews and the video-recorded lesson (see Appendix 1). The interviews were conducted immediately after the lesson and the questions were related to how the lesson had gone in terms of the knowledge, teaching and learning processes that had taken place.

\section{Identifying didactic moments}

When the lessons at a particular school had been video-recorded the researchers viewed and re-viewed the recordings in order to identify events that from our theoretical point of view could have significance for student learning. The identified events, here called didactic moments, are similar to Amade-Escot's (2005) critical didactic incidents with its roots in psychology and used within a French didactique tradition, and what Rønholt (2002) describes as a 'didactic irritation'. All these concepts share the purpose of facilitating researchers to extract significant events for further analysis where the different starting points of each concept help to identify incidents reasonable within that particular theoretical perspective. Didactic irritation initially developed from a phenomenological starting point (Rønholt, 2002) is described as:

... my felt irritation or disturbance about a situation during my observations, as noted in my field notes. However, to be termed a 'didactic' irritation it needed to be shown to have an important influence on the teaching or learning process, as demonstrated through a close analysis of the video. I consider didactic irritations to be general and dynamic phenomena, which from my perspective provide knowledge about processes that demand didactic, pedagogical reflections and discussions, which in turn could lead to alternative thinking and understanding about teaching and learning. Thus didactic irritations incorporate possibilities for change for the teacher and the students. (26-27)

In our approach, a didactic moment, which we use as an important basis for our interviews, is defined as an event in an explored lesson in which individual, social or cultural/institutional aspects of learning seem to play an important role in the learning process that is taking place. For example, this can include how students re-actualise their previous experiences of sport, music or other lessons (the individual), how students communicate verbally or embodied with each other (the social), or how the aims of the lessons clearly guide the students in a certain direction (the cultural/institutional). Identifying a didactic moment is about viewing and re-viewing the video recordings in order to identify events where teachers' and students' actions seem to be 'influenced' by the aspects mentioned and thus shapes the course of the event in terms of learning. This can start with actions from students or teachers, but can also sometimes be guided by the purpose of the 
lesson, such as learning a specific sport, or how students act in relation to purposes originating outside the institutionalised practice, for example, body ideals in society, or physical movement in music videos (see Quennerstedt, 2013). A didactic moment begins with a recognisable change of action in the ongoing processes of learning that alters the course of the event, and often closes when things go back to 'normal'.

\section{Didactic moment interviews}

Using the identified didactic moments as a base for questions and discussions, teachers and students were interviewed shortly after the lesson had been video-recorded. The interview with the teacher (Appendix 2) starts with general questions about the teacher, the subject, the teaching and the assessment process, in order to retrieve as much data as possible about the cultural/institutional aspects. After this, between four and six didactic moments lasting between 1-4 min were then shown and the teachers were asked to talk about what happened in the sequence and to say something about students' learning, knowledge and assessment in relation to the recording.

In the didactic moment interviews with the students (Appendix 3), at least three students from each school were selected for interviews. The choice of students was strategic in the sense that those selected were either clearly involved in or initiated the didactic moment. Where possible, we also selected a mixture of boys and girls for the interviews. The interviews with the students began with general questions about the students' interests, the subject of PE, the teaching and the assessment process. After this, the identified didactic moments were shown and the students were asked to talk about what happened in the sequence. The students were also asked to say something about the purpose of the lesson, their learning process and the teachers' assessment in relation to the didactic moments.

\section{Working with the data}

The interview data were transcribed verbatim and the video-recorded data was organised in separate files relating to the schools, the lessons and the handheld versus stationary camera. The didactic moments were tagged and sequenced in terms of which moments were selected and when they occurred in the recording.

In the project, the practice of PE and the learning going on there is in focus. The videorecordings of the PE lessons thus constitute the base data, because these represent the events of learning taking place. The various interviews then complement the visual data and add to the explored event, especially with regard to the individual and institutional/cultural aspects of learning, such as students' previous experiences or how discourses outside the particular learning site come into play in the situation. For example, as the ongoing practice is the main focus of the analysis, the purpose of the lesson is derived from the data as a whole - the video recordings and the interview material. Hence, the purpose(s) that the teacher communicates to the students during the lesson, and the purpose(s) or 'ends-in-view' (Quennerstedt, 2013) that are relevant and reasonable in students' actions, are also taken into account in the analysis.

As indicated, it is important that all aspects of learning are taken into consideration in the analysis of the visual and interview data. However, this is often done by or through the research questions and by highlighting one of the aspects without removing the other aspects from the analysis. Hence, all three aspects are investigated in the explored ongoing practice of PE by means of the data collected. The focus is thus on the learning that occurs in that particular practice. 


\section{What can we claim by using this approach?}

So far we have described the thinking behind the method and the methodological steps used in our study. But what can we claim by using this approach?

As previously argued, we maintain that student learning in PE can, using sociocultural learning theory, be attended to as a process in which individual, social and cultural/institutional aspects can be explored as different aspects of learning processes going on in PE practice. By using an approach that includes curriculum documents, pre- and post-lesson teacher interviews, videorecorded PE-lessons, and didactic moments interviews with teachers and students, we can get closer to these complex processes and thus explore the different aspects of the didactic system in the processes taking place in the gym. We can consequently get an additional understanding of what and how students learn in school during PE that involves an amalgamation of an explicit learning theory with robust methods (see Amade-Escot and O'Sullivan, 2007; Chen and Ennis, 2004; Deglau and O'Sullivan, 2006; Dyson et al., 2010; Kirk and Macdonald, 1998; Light, 2011; Rovegno et al., 2001; Verscheure and Amade-Escot, 2007; Ward and Lee, 2005).

\section{An illustration}

Due to the limitations of space, the focus of this illustration will be on the individual aspect of learning. As we previously have mentioned we are then putting the other aspects in the background, but without taking them out of the equation since they both theoretically and in practice overlap and are inextricably intertwined. In order to clarify the methodological idea step-by-step, and thus illustrate the potential of the method, we have chosen to emphasise students' individual experiences and how these experiences affect an ongoing learning process. The other aspects will be briefly mentioned in the illustration.

Focusing on the individual aspect of the learning process is accordingly about exploring how individuals make new meanings by recalling previous experiences and relating them to their experiences of the present situation (see Öhman and Östman, 2007; Wickman and Östman, 2002). We therefore show how different individual experiences are re-actualised in PE practice by using data from a video-recorded lesson in combination with pre- and post-lesson interviews and didactic moment interviews.

In this illustration we observe an aerobics lesson in an upper secondary school. The lesson is part of a vocational programme and involves 17 boys and two girls. In the pre-lesson interview, the teacher states that this lesson is part of a theme relating to dance and movement to music and that the students are going to continue working with aerobics to music as in the previous lesson. In the previous lesson the teacher showed the students how to develop a sequence of aerobic movements up to 32 beats. In this second lesson the aim is to practise these moves and create a sequence of two times 32 beats and to add arm movements to the steps. From the pre-lesson interview we know that the general aim of the lesson is to create an aerobics sequence. These are features that, together with localities, artefacts and the music used, can be seen as part of a cultural/institutional aspect of the event.

The lesson starts with a game called dance tag in order to warm up. After the warm-up the students are asked to work in the same groups as the previous lesson. The students who did not attend that first lesson are divided into the existing groups by the teacher. The task for the day is to practise and put together steps from the teacher prepared work sheets referred to as A and B blocks. ${ }^{2}$ At the beginning of the lesson the teacher also instructs the students who attended the first lesson to 
teach the 'new' students the moves. The teacher continues by saying that when the students have learned the steps, they should add arm movements.

In this lesson we identified a didactic moment involving a group of five boys. Three of the boys had worked with the blocks in the previous lesson, whereas the other two had not. The didactic moment was selected on the grounds of the way the teacher had organised the lesson and given the students space to act, and the way that one of the students in the event had taken charge of the situation and demonstrated to the others in the group that he knew the steps. In this we identified a potential learning situation.

At the beginning of the event the handouts with the described steps are distributed by the teacher.

Teacher: Here, you have two papers to look at.

$[\ldots]$

The group assembles and studies the handout.

Student 1: We will repeat what we did last time.

Student 1 starts by showing the steps to the others.

Student 2 starts by trying a few steps, while student 1 follows and accompanies the steps with instructions in time to the music.

Student 1: So, so, so, so ... so, so, so, so.

Student 1 demonstrates the steps quite quickly (but not correctly, our comment). The other students watch.

Student 2: Well ... shall we do it like this?

$[\ldots]$

At this point the teacher calls for attention.

Teacher: Listen ... some students weren't here last time ... so you'll have to teach them the moves ... so then you need to rehearse more... OK? ... there you go. Let's put the music on.

The students begin to practise in their groups.

$[\ldots]$

Student 1: Shall I show you?

Student 3: I don't know how to do it.

Student 1 repeats: Shall I show you the blocks?

Student 4: Show the blocks.

The teacher starts the music.

Student 1: Oh, shall I start - who knows the steps? You two know them... you can follow.

The two students who were present at the previous lesson stand beside student 1 .

Student 1 counts: five, six, seven, eight. 
Student 1 starts to do the steps with students 2 and 3 while counting.

Student 1: One, two, three, four, one, two, three, four five six seven eight...

$[\ldots]$

After demonstrating the set of moves student 1 says:

Student 1: That's good ... now you can do it yourself.

Up to now student 5 has been watching the others. At this point he starts to practise the steps with the others. The others follow student 1 and stand alongside and behind him so that they can see his moves.

From time to time they discuss what to do and which steps/ arm movements should be performed.

What, then, can we say from this didactic moment? In our view, we can explore how the students relate to the stated purpose of the lesson in terms of (a) practising the movements learned in the previous lesson, (b) practising the moves and creating a sequence of two blocks involving arm movements, and (c) involving those students who did not attend the first lesson. In this way, the students fulfil the institutional purpose of the lesson, and if the cultural/institutional aspect had been emphasised we could, for example, have explored the learning process against the background of how aerobics as a physical activity is viewed and used in Swedish PE.

We can observe a change of embodied actions among some of the students - they have learned to create a sequence of two blocks. However, although in this illustration the focus is on the individual aspect of learning, we can also claim that the social aspects impact the learning situation in that student 1 takes the lead and the other students follow. This can be explored as a potential power relation in terms of how students act on the initial actions of another student within the practice of PE. Regardless of whether they attended the first lesson or not, all the students allow student 1 to assume this role. If the social aspect of learning had been in the foreground we could, for example, have asked how the students helped each other to learn and which direction the learning veered.

However, in this paper we are interested in why student 1 assumes the leading role in this learning situation. Had the teacher asked some of the students to take the lead? As this question cannot be answered by watching the video-recorded lesson, we turned to the post-lesson interview and the didactic moment interview with the teacher.

In the post-lesson interview the interviewer asked the teacher for his view of the lesson, and in particular why certain students 'took the lead':

Teacher: I'm pleased in that they're safe with each other, that it's okay not to be, not to be good... and I'm very pleased with that. And also that some of them, or most of them, could manage these two blocks.

Interviewer: I thought it was interesting to see that every group had a leader.

Teacher: I thought so too.

Interviewer: One in each group stepped forward and took charge...

Teacher: And that's... I really like that.

The interviewer followed up the theme of 'taking charge' in the didactic moment interview with the same teacher and showed the above event of student 1 taking the lead: 
Interviewer: What did you do to get a leader to step forward in every lesson? Was that something you had decided in advance?

Teacher: I said that it would be an advantage. I said that ... those of you who think that you can master this...

Interviewer: And that was enough?

Teacher: Yes.

$[\ldots]$

Interviewer: From where have you taken the design for the lesson?

Teacher: A thought here is ... The advantage I have when I teach social sciences classes. As my knowledge is quite limited. If I have a female group or a mixed group, then some of the girls become... If you'd have recorded a female class ... then you'd have seen one leader in every group... They have more knowledge than I have. I wanted to teach aerobics. So when I planned this I thought how can I, with my limited ability and knowledge in aerobics, teach aerobics meaningfully to the students?

$[\ldots]$

Interviewer: What does this construction class do that is so special?

Teacher: They're trying . and then I think. I was lucky also I did not tell student 1 to step forward as a leader ... I couldn't know that there was a leader in every group ... and then I think ... what this class said about the evaluation: 'You said you weren't good at this and that the important thing was to try. Hence also we tried'.

Concerning learning aerobics, the teacher concluded by stating: 'I can't really teach them much. There is not enough time for this. If they don't have any ability before ... then it is not working'. The post-lesson interview and didactic moment interview give us additional clues to the learning that took place in this event. In the above excerpt, the teacher states that he has been clear from the start about his own limited knowledge of dance and aerobics, something that could be considered if putting the cultural/institutional aspect in the foreground. Therefore he leaves it to the students to take responsibility for the learning situation. It is also important to note that the teacher does not say which pupils should come forward and assume a leadership role. Although we are able to glean additional information from the interviews, we are still not sure why student 1 takes the lead in this particular learning situation. Also, as we are not sure which experiences the student re-actualises, we turn to the didactic moment interview with the student to find out more.

In the didactic moment interview with the student the researcher starts by showing the video clip of the same didactic moment that was presented to the teacher with a view to finding out why he took the lead.

Student 1: Was it, was it the second lesson? Tim and the others weren't at the previous lesson, so I wanted to explain it to them.

Interviewer: How come that it was you who explained?

Student 1: Because I was the leader the lesson before ... so when we practised the time before ... and we had to count, I was... and it was me who stood up there and showed the others what to do. I had never done this before either. 
Interviewer: How come that it was you then?

Student 1: Probably because it was easy for me, I guess.

Interviewer: Do you have any background?

Student 1: No, I've never danced before.

Interviewer: How did you learn it?

Student 1: Probably because in boxing there's damn much coordination...

Interviewer: Just that?

Student 1: It's probably coordination ... boxing is coordination. We did a ballet thing in boxing, a ballet warm-up or exercise, there's coordination in boxing, I can say that.

Interviewer: Was it experience that made you?

Student 1: That was why, that experience helped me here... [points to a boy in the video] He has also practised boxing, so he learned fairly quickly you see. But those steps they're... quite accurate as basic steps for boxing as you will learn, called 'the cross', you go side - side, straight forward, steps straight backward.

Interviewer: OK, so you had a base that you could then?

Student 1: Yes, probably, it was the...

Interviewer: ... What is his name [pointing to another boy in the video]?

Student 1: Chris!

Interviewer: Why didn't he take the lead?

Student 1: He wasn't at the first lesson.

What does this add to our knowledge about the learning situation and, in particular, which previous experiences the student re-actualises in the situation? In the didactic moment interview the student says that he 'had never done this before either'. At the same time, he relates the situation to the experience of boxing and that boxing is 'a hell of a lot of coordination'. He also relates to a ballet warm-up in a boxing class - 'that experience helped me'. The student clearly relates the learning situation at hand to his previous experiences. In this situation, we can demonstrate that students' experiences of movement in sport outside school PE are relevant to what happens in the specific learning situation. The transcript also shows how individual aspects of learning are always rooted in cultural/institutional and social experiences (see Kirk et al., 2000). We can, for example, see how a certain cultural aspect - a sport discourse - comes into play in PE in this situation and how that affects students' learning in the creation of aerobic sequences. However, we would also argue that a didactic moment interview that makes use of video clips facilitates a deeper investigation of the types of experiences that students bring into the learning situations in PE practice, and how previous experience affects the learning outcomes. How students re-actualise their previous experiences can sometimes be identified in the video recording alone, although the type of experience that is re-actualised is, as we have shown above, often difficult to determine. Non-verbal embodied experiences fall into this category. Unlike the other data, the didactic moment interviews allow us to explore how different individual experiences come into play with the cultural/ 
institutional and social aspects of learning in relation to the purpose of the lesson as well as what happened in it.

\section{Illustration summary}

In the above illustration we see that Student 1 takes the lead in order to accomplish the task at hand. From the interview with Student 1 we also know that he has no previous experience of aerobics, but instead makes use of his boxing experience and the skills and steps learned in his boxing practice. In this way, embodied knowledge from outside the particular learning site contributes to the learning that is taking place during the aerobics lesson.

By admitting his own lack of knowledge of dance and aerobics, we can also see how the teacher encourages the students to take charge of the situation even if they do not have any knowledge of aerobics. This part of the design and plan of the lesson makes it possible for the student to step forward at the appropriate time. It also allows a group of relatively unskilled (from an outsider's perspective) students to create something beyond what they would have been able to achieve by simply following the teacher's lead.

\section{Concluding remarks}

In this article we have used sociocultural learning theory together with robust and rigorous methodological steps to show a way to explore different aspects of learning in PE practice. This approach involves exploring and describing the participants in the learning situation by means of the functions they constitute in the explored ongoing practice. Individual, social and cultural/ institutional aspects are accordingly investigated with a point of departure in the explored ongoing practice of PE, with a particular focus on the learning that occurs in that particular practice. Although the comprehensive and sequential use of research elements such as videotaping, interviewing, framing purposes, and developing research questions are not in themselves unique in studies of PE, the use of these in conjunction with a specific theory of learning focussing on individual, social, and cultural/institutional aspects of learning is more unique, as is the specific underpinning use of didactic moments.

Although the work conducted within the French didactique tradition makes it possible to explore how teachers/teaching, students and content knowledge are all linked together in the didactic system, and studies within a situated learning tradition facilitate an exploration of how students actively engage with institutionalised subject matter, our examination potentially also handles the first three concerns that Hodkinson and colleagues (2007) argue for in studies of learning. This is useful, because it also allows us to consider individual differences in learning as well as wider social and cultural influences. By focusing on actions, this approach makes it possible to take issues of power relations in the learning situation into account, which involves adding a theory of power to the sociocultural learning theory (see, for example, Wertsch, 1998). In this way we complement situated approaches with a clear involvement of individual experiences in our studies, and didactique approaches by also involving issues of power as well as wider social, cultural and structural influences on the learning situation (for empirical examples see, Larsson et al., 2014; Quennerstedt et al., 2014).

As has been shown, this methodological strategy facilitates the exploration of different, but at the same time overlapping, individual, social and cultural/institutional aspects of learning. In this way the approach opens up research questions about teaching, learning, situation or assessment by focusing on the learning taking place in PE practice and thus adding to knowledge about what 
students learn in school PE. The potential lies in the spectrum of possible research questions about learning that can be explored by using a combination of an explicit learning theory, well-defined methodological steps and a multiple data collection strategy. This is also what makes our claims about exploring learning in PE possible.

\section{Appendix I}

\section{Pre- and post-lesson teacher interviews}

Pre-lesson $(\sim 10 \mathrm{~min})$

- Tell us about the forthcoming lesson (are there any lesson plans?)

- What does the lesson include? What kind of assignments will students work with?

- What is the purpose of the lesson? What is the idea behind the lesson?

- Is the lesson part of a larger theme or series of lessons?

- What are the students expected to learn? Should the students learn anything in particular?

- Does this content cause problems, and if so, which? What do students find difficult? Is there a large variation between able and less able students?

- How do you usually work with this? To what degree can you individualise the approach?

See the questions as a guide to the kind of content the interviews should contain. Give the teachers room to talk.

Post-lesson $(\sim 5 \mathrm{~min})$

- Can you tell me about the lesson? What thoughts do you have about how the lesson worked?

- Did anything special happen? Was there anything that did not go as you planned? Did anything surprise you?

- How did the students manage the assignments? Was the variation between able and less able students what you expected?

- Did anything happen during this lesson that you can use in your assessment documentation prior to grading the students?

- Will this lesson be followed up? What is the next step?

- I noticed that ... (something observed during the lesson)... Can you say something about that?

\section{Appendix 2}

\section{Teacher didactic moment interview}

Questions about the teacher

- How long have you been working as a PE teacher? How long have you been at this school?

- Where did you do your PE teacher training? When?

- Have you completed any Continual Professional Development (CPD) courses? In which area?

Questions about PE

- What in your view is the main objective of physical education and health?

- What do you regard as important knowledge in the subject? What should students learn? 
- Do you think that students understand what PE is all about? Are there significant differences in this between students?

Questions about teaching

- How do you plan a full term?

- How carefully do you plan the various elements/lecture series/lessons?

- Can you carry out the teaching in the way you want, or do you have to makes compromises?

- What does a normal lesson look like?

- Are there times when your ambitions for the lesson clash with the ideas of the students?

Questions about assessment

- How do you determine when a lesson is going well? How do you know when the students are working towards the intended goals?

- What type of feedback do you give students?

- How you assess the students? What is the basis for the assessment? Which documents do you need to perform the assessment? What characterises an A (highest grade) student and an E (lowest grade) student?

Didactic moments

- Ask the teacher to comment on the selected didactic moments.

- Tell us about what happens in this sequence. Try questions like: Why did you say that?/Why did you do that? Why did you give that kind of feedback?

- Would you say that the students have 'grasped' what the activity is aiming at?

- What do you think the students learn?

- How do you assess their knowledge? How do you grade the students? Why/why not?

\section{Appendix 3}

\section{Student didactic moment interview}

Questions about the student

- Ask them to introduce themselves (What are your interests? What is it like to go to school?, etc.)

Questions about PE

- Why do we have physical education in school?

- What do you learn in physical education? Can you say something about what you are supposed to know in relation to PE after finishing school?

Questions about teaching

- What does a school year look like in PE? Do you receive a schedule? Do you look at it, so that you know what is happening in each lesson?

- Do you work with specific assignments or activities for several lessons in a row, or are new things introduced in every lesson?

- What does a typical PE lesson look like?

- Do you understand the aims of the lessons? 
Questions about assessment

- What kind of comments does the teacher make? Is most of the feedback to the whole group, or do you also get individual feedback?

- Do you know what the grading criteria are? Can you tell us about them? Which grade did you get? Do you feel it was a fair grade - why/why not?

- Do you learn anything during PE?

Didactic moments

- Ask the student to comment on the selected didactic moments.

- Tell us what happens in this sequence. (Try questions like: Why did you say that?/Why did you do that?)

- What does the activity / assignment involve?

- Did you learn anything you didn't know before?

- (If so) Did you learn it at school or elsewhere?

- Do you practise this in other situations (at school, leisure)?

- Do you think that this (whatever it is/what they do) has any bearing on the teacher's assessment and your grades?

\section{Acknowledgements}

The authors would like to thank the two anonymous reviewers for their careful reading and helpful suggestions.

\section{Funding}

This research was conducted within the project 'Physical Education and Health - a Subject for Learning?' funded by the Swedish Research Council, grant number: 2010-5182.

\section{Notes}

1. Sociocultural learning theory building on Vygostky or Dewey often used in the Nordic countries, northern Europe and by researchers in Northern America is not to be equated to sociocultural perspectives in general where many studies using critical pedagogy and/or theorists like Foucault and Bourdieu have made an important impact on the field of PE. For an overview of a sociocultural perspective on curriculum change see, for example, Cliff (2012).

2. Block A (32): walk (16), step touch (8), side by side (8). Block B (32): V-step (8), A-step (8), high knee (8), walk (8), walk forward (8).

\section{References}

Almqvist J, Kronlid D, Quennerstedt M, et al. (2008) Pragmatiska studier av meningsskapande. Utbildning and Demokrati: Tidsskrift för Didaktik och Utbildningspolitik 17(3): 11-24.

Alvesson M and Sköldberg K (2000) Reflexive Methodology. London: Sage.

Amade-Escot C (2005) Using the critical didactic incidents method to analyze the content taught. Journal of Teaching in Physical Education 24(2): 127-148.

Amade-Escot C (2006) Student learning within the didactique tradition. In: Kirk D, Macdonald D and O'Sullivan M (eds) The Handbook of Physical Education. London: Sage, pp.347-365.

Amade-Escot C (2008) Physical education as culture: How research may grasp the cultural features of this integrated process. Keynote lecture at Association Internationale des Ecoles Superieures d'Education Physique (AIESEP) World Congress, Sapporo, Japan, 21-24 January 2008. 
Amade-Escot C and O'Sullivan M (2007) Research on content in physical education: Theoretical perspectives and current debates. Physical Education and Sport Pedagogy 12(3): 185-203.

Barker DM, Barker-Ruchti N and Pühse U (2013) Constructive readings of interactive episodes: Examining ethics in physical education from a social constructionist perspective. Sport, Education and Society 18(4): $511-526$.

Brown T and Penney D (2013) Learning 'in', 'through'and 'about'movement in senior physical education? The new Victorian Certificate of Education Physical Education. European Physical Education Review 19(1): 39-61.

Chen A and Ennis C (2004) Goals, interests and learning in physical education. The Journal of Educational Research 97(6): 329-339.

Cliff K (2012) A sociocultural perspective as a curriculum change in health and physical education. Sport, Education and Society 17(3): 293-311.

Cobb P and Bowers J (1999) Cognitive and situated learning perspectives in theory and practice. Educational Researcher 28(2): 4-15.

Deglau D and O'Sullivan M (2006) The effects of a long-term professional development program on the beliefs and practices of experienced teachers. Journal of Teaching in Physical Education 25(4): 379-396.

Dyson B, Linehan N and Hastie P (2010) The ecology of cooperative learning in elementary physical education classes. Journal of Teaching in Physical Education 29(2): 113-130.

Evans J, Davies B and Penney D (1996) Teachers, teaching and the social construction of gender relations. Sport, Education and Society 1(2): 165-183.

Evans J, Davies B and Rich E (2009) The body made flesh: Embodied learning and the corporeal device. British Journal of Sociology of Education 30(4): 391-406.

Evans J, De Pian L, Rich E, et al. (2011) Health imperatives, policy and the corporeal device: Schools, subjectivity and children's health. Policy Futures in Education 9(3): 328-340.

Gillespie L (2013) Assessment in physical education: A sociocultural perspective. Teachers and Teaching 19(2): 235-238.

Hay P and Penney D (2012) Assessment in Physical Education: A Socio-Cultural Perspective. London: Routledge.

Hodkinson P, Biesta G and James D (2007) Understanding learning cultures. Educational Review 59(4): 415-427.

Hodkinson P, Biesta G and James D (2008) Understanding learning culturally: Overcoming the dualisms between social an individual views of learning. Vocations and Learning 1(1): 27-47.

Ivinson $\mathrm{G}$ (2012) The body and pedagogy: Beyond absent, moving bodies in pedagogic practice. British Journal of Sociology of Education 33(4): 489-506.

Jess M, Atencio M and Thorburn M (2011) Complexity theory: Supporting curriculum and pedagogy developments in Scottish physical education. Sport, Education and Society 16(2): 179-199.

Kirk D and Macdonald D (1998) Situated learning in physical education. Journal of Teaching in Physical Education 17(3): 376-387.

Kirk D, Brooker R and Braiuka S (2000) Teaching games for understanding: A situated perspective on student learning. Presented at the American Educational Research Association Annual Meeting, New Orleans, USA, 24-28 April 2000.

Kirk D and MacPhail A (2002) Teaching games for understanding and situated leaning: Rethinking the bunker-Thorpe model. Journal of Teaching in Physical Education 21: 177-192.

Kirk D, Macdonald D and O'Sullivan M (eds) (2006) The Handbook of Physical Education. London: Routledge.

Larsson H, Quennerstedt M and Öhman M (2014) Heterotopias in physical education: Towards a queer pedagogy? Gender and Education. DOI:10.1080/09540253.2014.888403

Lave J and Wenger E (1991) Situated Learning: Legitimate Peripheral Participation. Cambridge: Cambridge University Press. 
Light R (2008) Complex learning theory - its epistemology and its assumptions about learning: Implications for physical education. Journal of Teaching in Physical Education 27(1): 21-37.

Light R (2011) Opening up learning theory to social theory in research on sport and physical education through a focus on practice. Physical Education and Sport Pedagogy 16(4): 369-382.

Macdonald D (2004) Understanding learning in physical education. In: Wright J, Burrows L and Macdonald D (eds) Critical Inquiry and Problem-solving in Physical Education. London: Routledge, pp.16-29.

MacPhail A, Kirk D and Griffin L (2008) Throwing and catching as relational skills in game play: Situated learning in a modified game unit. Journal of Teaching in Physical Education 27: 100-115.

Öhman J and Östman L (2007) Continuity and change in moral meaning-making - a transactional approach. Journal of Moral Education 36: 151-168.

Öhman M and Quennerstedt M (2012) Observational studies. In: Armour K and Macdonald D (eds) Research Methods in Physical Education and Youth Sports. London: Routledge, pp.189-203.

O'Sullivan M (2013) New directions, new questions: Relationships between curriculum, pedagogy, and assessment in physical education. Sport, Education and Society 18(1): 1-5.

Quennerstedt M (2013) Practical epistemologies in physical education practice. Sport, Education and Society 18(3): 311-333.

Quennerstedt M, Almqvist J and Öhman M (2011) Keep your eye on the ball: Investigating artifacts-in-use in physical education. Interchange 42(3): 287-305.

Quennerstedt M, Öhman M and Armour K (2014) Sport and exercise pedagogy and questions about learning. Sport, Education and Society. DOI:10.1080/13573322.2013.847824

Quennerstedt M, Öhman J and Öhman M (2011) Investigating learning in physical education. A transactional approach. Sport, Education and Society 16(2): 159-177.

Rogoff B (1995) Observing sociocultural activity on three planes: Participatory appropriation, guided participation, and apprenticeship. In: Wertsch J, Del Rio P and Alvarez A (eds) Sociocultural Studies of Mind. Cambridge: Cambridge University Press, pp.139-164.

Rønholt H (2002) 'It's only the sissies': Analysis of teaching and learning processes in physical education: $\mathrm{A}=$ contribution to the hidden curriculum. Sport, Education and Society 7(1): 25-36.

Rovegno I (2006) Situated perspectives on learning. In: Kirk D, Macdonald D and O'Sullivan M (eds) The Handbook of Physical Education. London: Sage, pp.262-274.

Rovegno I and Dolly J (2006) Constructivist perspectives on learning. In: Kirk D, Macdonald D and O'Sullivan M (eds) The Handbook of Physical Education. London: Sage, pp.242-261.

Rovegno I, Nevett M and Babiarz M (2001) Learning and teaching invasion-games tactics in 4th grade: Introduction and theoretical perspectives. Journal of Teaching in Physical Education 20(4): 341-351.

Säljö R (1998) Learning inside and outside schools: Discursive practices and sociocultural dynamics. In: Roberts DA and Östman L (eds) Problems of Meaning in Science Curriculum. New York and London: Teachers College Press, pp.39-53.

Säljö R (2009) Learning, theories of learning, and units of analysis in research. Educational Psychologist 44(3): 202-208.

Sfard A (1998) On two metaphors for learning and the dangers of choosing just one. Educational Researcher 27(2): 4-13.

Verscheure I and Amade-Escot C (2007) The gendered construction of physical education content as the result of the differentiated didactic contract. Physical Education and Sport Pedagogy 12(3): $245-272$.

Vygotsky LS (1986) Thought and Language. Cambridge, Massachusetts: Harvard University Press.

Wallian N and Chang CW (2006) Language, thinking and action: Towards a semio-constructivist approach in physical education. Physical Education \& Sport Pedagogy 12(3): 289-311.

Ward P and Lee MA (2005) Peer-assisted learning in physical education: A review of theory and research. Journal of Teaching in Physical Education 24(3): 205-225.

Wertsch JV (1998) Mind as Action. Oxford: Oxford University Press. 
Wickman PO and Östman L (2002) Learning as discourse change. A sociocultural mechanism. Science Education 86(5): 601-623.

Wright J, Burrows L and Rich E (2012) Health imperatives in primary schools across three countries: Intersections of class, culture and subjectivity. Discourse: Studies in the Cultural Politics of Education 33(5): 673-691.

\section{Author biographies}

Mikael Quennerstedt is Associate Professor in Education (physical education) at the School of Health and Medical Sciences, Örebro University, Sweden.

Claes Annerstedt is Head of Department at the Department of Food and Nutrition, and Sport Science, University of Gothenburg, Sweden.

Dean Barker is Associate Professor at the Department of Food and Nutrition, and Sport Science, University of Gothenburg, Sweden.

Inger Karlefors is a Senior Lecturer in Pedagogy (physical education) at the Department of Education, Umeå University and Luleå university of Technology in Sweden.

Håkan Larsson is Professor of Physical Education and Sport Pedagogy at The Swedish School of Sport and Health Sciences in Stockholm (GIH).

Karin Redelius is Pro Vice-Chancellor and Associate Professor in pedagogy at the Swedish School of Sport and Health Sciences in Stockholm (GIH).

Marie Öhman is Associate Professor in Sport Science at the School of Health and Medical Sciences, Örebro University, Sweden. 